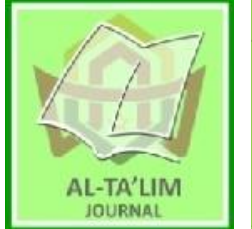

AL-TA'LIM JOURNAL, 27 (1), 2020, (58-71)

(Print ISSN 1410-7546 Online ISSN 2355-7893)

Available online at http://journal.tarbiyahiainib.ac.id/index.php/attalim

\title{
Techniques of Using Intertextuality and Lecturer-Students' Power Relation when Communicating Learning Tasks
}

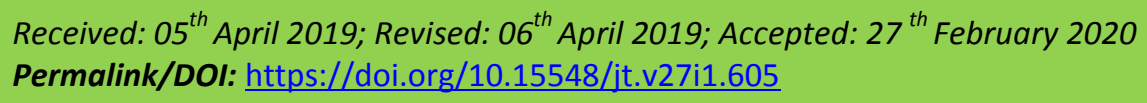

\section{Yelfiza *)}

Sekolah Tinggi Keguruan dan Ilmu Pendidikan PGRI Sumatera Barat, Indonesia.

E-mail: yelfiza@stkip-pgri-sumbar.ac.id

\section{Yulmiati}

Sekolah Tinggi Keguruan dan Ilmu Pendidikan PGRI Sumatera Barat, Indonesia.

E-mail: yulmiati@stkip-pgri-sumbar.ac.id

\section{Rika Afriyanti}

Sekolah Tinggi Keguruan dan Ilmu Pendidikan PGRI Sumatera Barat, Indonesia.

E-mail: rikaafriyanti@stkip-pgrisumbar.ac.id

\section{Syayid Sandi Sukandi \\ Sekolah Tinggi Keguruan dan Ilmu Pendidikan PGRI Sumatera Barat, Indonesia. \\ E-mail: syayidsandisukandi@stkip-pgri- sumbar.ac.id}

\section{*) Corresponding Author}

\begin{abstract}
Considering the students' emotion is essential in having the students to learn. Most Minangkabaunese students do not like being dictated for any activities with a thousand words. This paper is aimed at finding out some techniques of using intertextuality to balance lecturer-students' power relations when communicating learning tasks. This research is qualitative with content analysis. Data were collected from six lecturers, teaching at Sekolah Tinggi Keguruandan Ilmu Pendidikan, Persatuan Guru Republik Indonesia (STKIP PGRI), selected purposively. Techniques of observation and video recording were used in collecting data. The discourse was transcribed and categorized into some techniques of using examples based on the content called content analysis. A contextual analysis was used to show lecturer-students' power relations and formulated proposition. Findings show that the techniques of using intertextuality includeShowing Techniques of Doing Tasks (STDT), Giving Example of the Task Topic (GETT), and UERS. Using STDT had an impact on students' readiness to learn. Meanwhile, Using GETT enhances students' language development. Finally, Using Example of Real Situations (UERS) gives students' opportunity to have a learning experience. Moreover, the techniquescause the lecturer and students to have a balanced power relation. The findings are significant for teachers or lecturers as guidance to communicate with students efficiently and effectively. They are expected not to dominate communication when interacting with them, especially to those who have excessive individualism. Other researchers who are interested in studying this topic are expected to be inspired to research this area viewed from other viewpoints.
\end{abstract}

Keywords: Example; intertextuality: power relation; communication; learning task.

How to Cite: Yelfiza, Y., Yulmiati, Y., Afriyanti, R., \& Sukandi, S. (2020). Techniques of Using Intertextuality and Lecturer-Student Power Relation When Communicating Learning Tasks. Al-Ta lim Journal, 27(1). doi:https://doi.org/10.15548/jt.v27i1.605

\section{INTRODUCTION}

Intertextuality is used by a lecturer when communicating learning tasks to provide students' knowledge acquisition. It makes the task clearer since it supports the idea presented by a text. However, it can be dysfunctional or lead the students to misunderstand the task if the techniques are not consistent with the students' cultural background (Gasparov, 2010 ; Nevins, 2010).

The fact that Minangkabaunese students of Indonesia have unique culture is depicted in their philosophy of "kato nan ampek" and one of them is called "kato manurun"(Navis, 1984 , p. 101). Kato manurun is the discourse used from the older to younger one or from the one who has a higher status to the lower 
one.However, some of the Minangkabaunese students have excessive individualism character which can cause them to be inattentive toward lecturers' words. Moreover, they dislike the domination of the lecturer's power in classroom interaction.

Regarding the character, to balance their power relation, Student-centered learning can be an appropriate approach to use. Itallows seeing the real model through example and to construct their example (Sternberg \& Williams, 2010; Weibell, 2011; Bandura, 2002). Besides, the students can use information, experiences, and thoughts and beliefs to construct meaning before and while doing the learning task (Learner-Centered Work Group of the American Psychological Association's Board of Education Affairs, 1997). Some experts pay attention to the context of schema theory, whichconcerns the role of knowledge and usesprevious knowledge as the main guiding context of information to process and interpret the task (Nassaji, 2007). However, the students still needa teacher's or lecturer's explanation of the learning task through guidance (Bondareva, Khan, Pristupa, Dossanova, Kremneva, and Rakymzhan Turysbek, 2017). Meanwhile, Vygotsky's theory about human connection and ideas, is probably conducive to continuous reinterpretation and wide dissemination of his ideas, but hardly beneficial for their understanding as an integrative theory of human cultural and biosocial development. Two problems are particularly notable. These are, first, numerous gaps and age-old biases and misconceptions in the historiography of Soviet psychology, and, second, the tendency to overly focus on the figure of Vygotsky to the neglect of the scientific activities of a number of other protagonists of the history of cultural-historical psychology. This study addresses these two problems and reconstructs the history and group dynamics within the dense network of Vygotsky's collaborators and associates, and overviews their research, which is instrumental in understanding Vygotsky's integrative theory in its entirety as a complex of interdependent ideas, methods, and practices. (Yasnitsky, 2011) is also useful to understand in constructing meaning. Following Vygotsky, lecturers can solve complex tasks based on the fundamental Sociocultural Theory (SCT) principle which enhances cognitive functioning in this article we argue that language functions as more than just a form of communication; it functions as a cognitive tool as well. The use of language to mediate complex cognitive functioning such as problem solving, attending, and recalling has been referred to as languaging. We demonstrate that languaging is associated with enhanced cognitive functioning in Agnes, a 94-year-old resident of a long-term care facility. The enhanced cognitive functioning was reflected in an increase in discourse builders and a decrease in discourse impairments over a 2-month period during which Agnes engaged in languaging activities. We suggest that volunteers could be trained to implement languaging activities, which take more time to implement than many staff members have (Swain, Lapkin, \& Deters, 2013) . Another expert used cognitive linguistic study which was "construal-based and construction-based" (Masuda, Arnett, \& Labarca,) and the two approaches were combined to become a principled contrastive constructional analysis. Following the previous theories, scheme theory, SCT, and student-centered learning model, researchers studied lecturer-students' social interaction in assisting students to learn and its' contribution to their power relation. This research is focused on the techniques of using examples as one type of intertextuality which can be contributed to lecturer-students' power relations since the use of example in interaction can decrease the lecturer's discourse domination.

Intertextuality used in the classroom isa linguistic activity to build the students' new language (Gasparov, 2010). It involves what the students knew before as background knowledge or experience. To Baker \& Sibonile (2011), it is the way of incorporating a text withthe aspect of other texts in one discourse. Thus, one genre 
involves exploration by using other genres in a discourse.

One type of intertextuality is an example by which a lecturer usually uses it to convey the meaning of a text instead of reducing the use of words. It is considered as intertextuality since the example is taken from what the students have experienced previously (Manak, 2011) in written or spoken discourse, so that the students can relate new information with the given example.

The theory of intertextuality is influenced by Vygotskian theories of learning and sociocultural theory (SCT) which emphasize the role of language and social interaction as key tools in supporting changes in a learner's understanding of how and what to communicate in particular sociocultural contexts (Warren, 2013). Also, intertextuality guides learners in interacting with the language which is used in published or classroom texts. It is a process that facilitates their understanding of how to read and write academic discourse (Harman, 2013). Moreover, Farquhar \& Fitzsimons find the power of language can create what is 'real' through image and metaphor. There are some types of intertextuality, such as "indirect reference, example, repetition, quotation, retelling, illustration, allusion, parody, translation, conclusion, challenge, warning, sarcasm, and claim" (Yelfiza, 2016; Yelfiza, Yulmiati, \& Sukandi, 2016), but in this research, we only study the example type, specific techniques of using examples in communicating learning tasks.

On the other hand, the topic of power in this research was viewed from an educational power perspective. It presumes that the lecturer has discourse power over the students to encourage maximum learning (Van-Dijk, 2008) . More powerful lecturer can control and dominate students as subordinates through discourse. She or he can control natural resources, as learning material, media, classroom situation, and interaction if they have privileged access to authority (Clare, Krogman, \& Caine, 2013) . On the other hand, Maeda (2008) argues that power relations may promote or impede students' learning development. Power relations include multi-directional, structured, context-specific, and strategic. The teacher draws attention to her potential to exercise power (Perumal, 2008), which is expressed through the way she or he communicates. Communication in learning can be in the form of instructional or personal communication. Instructional communication is done when students feel that they do not have an interpersonal relationship with their lecturer. Their relation is more functional and their relationship is a superior-inferior relationship. The lecturer becomes a leader, supervisor, mentor, source of information, and other functions that serve their students in learning. Using a convenience sample, 172 college students' motives for communicating with their instructors and their own verbal aggressiveness and argumentativeness were studied using the Argumentativeness Scale, the Verbal Aggressiveness Scale, and the Student Motives to Communicate Scale. Significant negative relationships were obtained between students' self-reports of argumentativeness and the sycophantic motive and between students' self-reports of verbal aggressiveness and the functional motive, but generally, students' motives to communicate with their instructors generally were not associated with their self-reported aggressive communication behaviors (Myers, 2017a). Thus, power relation changes the classroom activities gradually from lecturer's domination to students' domination. Therefore, this research is proposed to find out the techniques of using examples used by lecturers when communicating learning tasks and the effect on lecturer-students' power relations.

\section{METHOD}

The method of research was qualitative content analysis with textual and contextual techniques of analyses.Participant was selected purposively based on the characteristics of the subjects they taught. They were English lecturers who taught Research in Language Teaching, Language 
Assessment, and Classroom Management at English Department, English Indonesian Translation, and Paper and Thesis Writing, at STKIP PGRI Sumatera Barat in 2016 and those who had been teaching there for more than five years. Six lecturers were observed with the consideration that they were teaching English subjects that were full of the task. However, only three out of them had given a variety of data, regarding the use of examples in communicating with their students. On the other hand, the number of students used as the primary context was those who were studying with the three lecturers. They were studying in the fifth semester. Besides, the samples of data were selected purposively considering the variety of data found during the research.

Data were collected by observation technique. The observation was done to each participant when they were teaching. The frequency of observation depended on the variety of data, and based on the variety, they were observed twice since the first and the second data did not show any varieties. While observing the students, we recorded their discourse along with the context of utterances. Next, only the data that used examples as the way to communicate learning tasks were purposively selected based on the variety. The data with the same characteristics were categorized in one group and only one sample of the data was taken for the analysis.

The data were analyzed using content analysis and contextual analysis. In content analysis, researchers break down the data into pertinent units of information for coding and categorized them so that the themes or the topics around which the discourse was developed could be formulated. Thus, After reading the data, researchers tried to extract and categorize them into some techniques of using examples, based on a variety of information. The subsequent analysis is called contextual analysis, which assumes discourse as a singular event, and is used to show power relations in the use of an example as intertextuality (Ruiz, 2009; Mayring, 2014). In this analysis, participant, situation, and cultural context were analyzed to understand the techniques of using an example.

\section{RESULTS AND DISCUSSION}

Having observed the six participants twice for each, researchers found three techniques of using examples implemented during their interaction in research class. The techniques include STDT (Showing Technique of Doing Task), GETT (Giving Example of the Task Topics), and UERS (Using Example of Real Situation). Each technique is described below to find out its relation to discourse power relations.

The following extract occurred when the lecturer (A) taught Language Assessment in a classroom discussion. The topic discussed was about curriculum change as the cause of the change in assessing the students' language competence. A group of students who presented a topic under the lecturer's control handled learning activities. The group of students stood in front of the class and became ready to present the topic. However, before the presentation, the lecturer used the following fragment of discourse.

\section{Extract 1 \\ ${ }^{1}$ Anda harus menyatakan pendapat anda, apa yang membuat anda, misalnya saya setuju lo Mis (You should tell your opinion, what makes you..., for example. I agree with you. 0:00:13)}

\section{Showing Technique of Doing Task (STDT)}

In the excerpt above, the example used by the lecturer is not related to the content, but it is an example of the way to express their opinion. She showed the way since she wanted the students to tell their opinion about the topic when presenting the material so that they became ready to present the topic as expected. This way increases the students' focus in the discussion because they know what to do in the presentation and what to respond after the presentation. The first finding showed that STDT is applied when classroom discussion is held by students, through an oral presentationwhich is initially preceded by some models of examples offered by the lecturer (LME) and followed by the students' model of examples (SME). The way can decrease the lecturer's power 
domination. Besides, when the students are allowed to understand a topic through a model and examine their understanding with their example, they become confident and more ready to learn and it will affect their oral presentation.

Inserting an example about how to express an idea, as found in the extract (1) above, "saya setuju lo Miss" will be futile before the students see examples of information. They do not understand the information yet, so to remind them, the lecturer can ask the class about what they will do in a discussion and write the answers on board. Moreover, the lecturer should consider the ways of using examples that depend on the context, for example, their students'experience, culture, interest, and motivation. Then, based on the contexts, she or he can use what and how to use examples while communicating the learning task. Therefore, in learning through example, "four important factors of initial motivation must face creation: the probability of success, anxiety, interest, and challenge" (Vollmeyer \& Rheinberg, 2006).

Minangkabaunese students fundamentally respect their teacher as the superior one and speak to the lecturer by using "kato mandaki" (Navis, 1984, p. 101) ; they cannot criticize him or her, even though the situation provides space for critique. They just listen and do what the lecturer asks even though they do not understand much of what was said. On the other hand, when the lecturer finds students nodding their head or smiling during her presentation, she must have two kinds of interpretation. One is that they cannot understand information at all and the other one is that they understand it thoroughly. Minangkabaunese students do not show their weaknesses to others, including to their lecturer. Even though they do not understand, they will pretend as if they understood, for example, justby smiling or being silent when they cannot answer a question. Scholars call this character as excessive individualism (Amir, 2011). In this way, by using examples, the lecturer limits the number of words in communication.
Eventually, the students respect the lecturer more, than use words beyond necessary.

Dictating some points to discuss followed by some questions may challenge the students. It may be to apply the principle of scaffolding, which indicates that if the students are guided, they can study all learning materials eventhough the materials are difficult. To help students, the lecturer can utilize a diagnostic strategy so that he or she can diagnose the students' capability to determine the type and the level of support to provide. However,in scaffolding attention to empirical scaffolding literature, such as (the students can see and experience the activity), is more attractive than ongoing diagnosis on students' understanding (Pol, Volman \& Beishuizen, 2011) . Therefore, a lecturer plays a role in providing the situation, which can facilitate or support the students' understanding of a topic and in guiding them to develop their knowledge.

In the pre-phase of teaching, the students' readiness to learn is essential, since it can have an impact on the outcome. Although many researchers have studied different factors which affect E-Learning outcomes, there is little research on assessment of the intervening role of readiness factors in E-Learning outcomes. This study proposes a conceptual model to determine the role of readiness factors in the relationship between E-Learning factors and E-Learning outcomes. Readiness factors are divided into three main groups including: technical, organizational and social. A questionnaire was completed by 96 respondents. This sample consists of teachers at Tehran high schools who are utilizing a technology-based educating. Hierarchical regression analysis is done and its results strongly support the appropriateness of the proposed model and prove that readiness factors variable plays a moderating role in the relationship between E-Learning factors and outcomes. Also latent moderated structuring (LMS) technique and MPLUS3 software are used to determine each variable's ranking. Results show that organizational readiness factors have the 
most important effect on E-Learning outcomes. Also teachers' motivation and training is the most important factor in ELearning. Findings of this research will be helpful for both academics and practitioners of E-Learning systems (Keramati, AfshariMofrad, \& Kamrani, 2011), but it cannot be continued if they are not engaged in the activity. Moreover, students' readiness to learn can lead them to have self-regulated learning. This article discusses pupils' readiness for self-regulation in Exploratory Production in Technology Education. In the forethought phase of Exploratory Production, pupils envision and regulate their technological production activities. Next, in the performance phase, the envisioned goals are tried and implemented through ideating, planning and manufacturing. Finally, in the self-regulation phase, the goals are tested with new products in their usage targets. The theoretical framework of self-regulated learning and empirical categorization of the data are based on Zimmerman's model (Selfregulated learning from teaching to selfreflective practice. The Guilford Press, New York, pp 1-19, 1998, Handbook of selfregulation of learning and performance. Routledge, London, pp 49-64, 2011). The focus of this article is on the forethought phase. The empirical analysis in this article is based on national evaluation data of Finnish compulsory education. The first national evaluation of learning outcomes in Technology Education (taught within the subject Craft) was implemented by the Finnish National Board of Education in spring 2010. The evaluation was carried out as two questionnaires for ninth graders with general $(n=4,792)$ and advanced $(n=1,548)$ questions, and a production exercise $(n=661)$. In this article, the data is analyzed further based on learners' comprehensions, leisure-time activities and classroom techniques. The article is part of a larger research project that aims to improve the national evaluation data. The results on pupils' readiness for self-regulation in the forethought phase of Exploratory Production are encouraging. Pupils' have positive comprehensions of the Craft \& Technology
$(\mathrm{C} \& \mathrm{~T})$ subject and they find learning useful for their current life and for the future. Learning tasks and producing tasks in the $\mathrm{C}$ $\& \mathrm{~T}$ subject could be even more related to pupils' own technological and functional experiences. More effort should be given to support pupils' readiness to regulate goals for their own technological production activities (Kallio, \& Virta, 2014). Acquiring upon their emotions to get involved in the topic such as by having an example or watching a video may help a lecturer attract the students' attention so that they can become more ready to study. Bandura in Krapp (2005) suggests that "people can learn simply by watching others, rather than by trial and error." Furthermore, he explains that there are some factors influencing students' readiness. The factors include the expected outcome, characteristics of the person being observed, such as age, sex, similarity to the observer, status, skill, and power, characteristics of the observer such as self-esteem, dependence, the experience of rewards, and mental and physical skill, characteristics of behavior such as simple or admired behavior. In short, the more the lecturer fulfills the factors, the more ready the students become.

Since the students' ability to comprehend written material was still an intermediate or below intermediate level, they were not ready yet to practice what the lecturer immediately explained. They did not even understand much of the material they had prepared outside of the classroom. Also, they could not change their presentation slides in the situation they felt nervous to present. Their reading interest was not yet fully developed well. So to link what the lecturer explained immediately with what they had prepared was a difficult task for them. Therefore, lecturer's solidarity is important (Hudson, 1985), When the power relation to force the students does not occur, it can change into solidarity. The lecturer can allow the students to learn independently and support them when needed.

Moreover, the students' cultural sensitivity of example is problematic. It was conditioned by what the students understood 
in the previous week. Itcould not be influenced by the new information incidentally. Consequently, the students misinterpreted Minangkabaunese's philosophy about a commitment to 'Kato dahulu kato batapati.' This expression relates to moral consistency in training honesty and obedience to apply a commitment (Syuhendri, 2012) . They thought that the lecturer was inconsistent in giving instruction.Khalidah, et al (2014) studied commitment with the result that the students' overall commitment to excellence was high. They found a consistent and significant correlation between ethical values and students' level of commitment to strive for excellence.

On the other hand, the theory of mind suggests thatthe teacher's comments motivate children to keep trying and promote academic achievement. Comments or questions about a topic can be given a week before a discussion. The lecturer can remind the students to discuss a topic based on the comments or the questions. Thus, during the discussion, the lecturer can apply a diagnostic strategy by giving comments and questions to know the level of the students' capability and determine which support they need from the lecturer (Pol, Volman, \& Beishuizen, 2011). Moreover, the theory of scaffolding and theory of mind (Mizokawa, 2014) includes consideration in choosing an activity based on the students' capability. The students' capability can be recognized through cultural context such as becoming silent or nodding their heads. By understanding their culture, the lecturers approach them by selecting discourse, which can increase their understanding or increasing their confidence by giving clear and detail examples. Moreover, the assessment approach with higher self-confidence and positive selfesteem associated with positive academic and clinical outcomes (Fixsen \& Ridge, 2012) indicate the importance of preparing and supporting students' prior knowledge at the initial period of practice.

\section{Extract 2}

The following extract occurred when the participant (B) taught Research in Language
Teaching 2 with the topic of Research Problem. Since the research subject was concerned with the students' skill rather than their knowledge of research, when explaining learning material, the lecturer explained indirectly the students' task. Her explanation comes through in the following fragment of discourse.

${ }^{2}$ Apa itu?Misalnya kawan saja, Nah,
makanya dalam kuantitatif question
wordnya adalah yes/no question, berbeda
dengan kualitatif.... What is it? For
example, only my friend, Well. Thus, in
quantitative research, the question word is
yes/ no question different from qualitative
research).

${ }^{3}$ Aaaa, dalam kualitatif dia akan melihat misalnya... (mmm, in qualitative, the study is about....

${ }^{4} \mathrm{Nah}$, kalau misalnya strategi.... (So, if

it is about the strategy...) (00:02:24).

\section{Giving Example of the Task Topics (GETT)}

Different from the first extract, excerpt 2 occurred when the lecturer explained the topic of Research about the research problem. The explanation involved the procedures, which they should follow in doing the task. She used examples of orally $(2,3$, and 4$)$, with different topics so that the students could choose which topic they preferred. Firstly the lecture asked a question about the topic, "What is it?" Soon she answered it by giving an example of a general topic (only my friend or strategy), with a clue, "In quantitative research, the question word is yes/no question different from qualitative research." She did not give a clear and complete example, then she ended an explanation by commanding students to find out their topic.

Intertextuality with the word 'misalnya' is similar to the previous data. In this discourse, the example is to explain the content rather than to show the way to use it. Besides, the use of 'saja' signals a limit. It does not include the others. One can find that when the students listen to much information about the task topics, they find difficult to 
focus their attention, and consequently, the information is not retained.

When the number of items retained in working memory is smaller than or equal to the capacity of the focus of attention, they will be contained within the focus, where they are immediately retrievable. On the other hand, when the number of items to retain exceeds the capacity of the focus, the excess items will be stored outside the focus of attention (Zhang \& Verhaeghen, 2009). Therefore, the lecturer should be careful to give information within the students' capacity.

One can see from the discourse that the lecturer dominated the classroom activities. She talked much without engaging the students to ask, comment, or answer the question because she answered her question herself. The learning approach was oriented to the lecturer. On the other hand, the lecturer's domination is decreased if some examples are given by the lecturer and some others are provided by students. In the discourse above, the lecturer provided examples of the topics by themselves after giving a question.

The second findingis about Giving Example of the Task Topic (GETT) done with different topics of example by using some procedures. Firstly, lecturers asked a question (AQ) and she answered it directly by giving general topics (GGT) and the clue (GC). In the end, the students respond to it by mentioning their research topic. However, when different topics are given by the lecturer at the same time in general, the students got difficulty understanding so that their learning development cannot proceed. In other words, such a technique gets the power relation unbalanced.

Minangkbaunese students tend to learn from examples as indicated by a suggestion below (Myrahil, 2013). Barajaka Nan Manang, Mancontoh Ka Nan Sudah. In learning, Minangkabaunese students need examples to inspire them to do something. Thus, a success story is very useful for them to understand when asked to do a learning task. Even though Minangkabaunese people have a cultural communication known as kato manurun, this form does not mean that only the senior has power in talking. The culture means that the young should consider what language to use when communicating with a senior. Moreover, as a communal society, Minangkabaunese people are much aware of cooperative communication called 'mufakat', which is reflected in the way they make decisions. One of their philosophical principles Bulek aia dek pambuluah, bulek kato dek mufakat (Nasroen, 1957, p. 61; Shalihin, 2014, p. 67) proving that no one may dominate a communicative event to have a satisfying result.

Explanation without including a real example that cannot be seen, asked, commented, or with an example that does not emerge from the students' experiences are more abstract, which might obstruct their comprehension. Dewey (1938) cited by (Varelas, Pappas, \& Rife, 2006) states that education should include co-operative activities, not a dictation; the development of the students occurs through reciprocal giveand-take between teacher and the students through the process of social intelligence. Moreover, learning is a combination of emphasis on engagement in hands-on explorations with an emphasis on children's literature information books, including the photographs or illustrations in them.

The following extract was taken from the discourse of participant (C) who taught Classroom Management. The students' seating position included forming a square, by which the lecturer could see all students' activities. She explained the topic of management strategy by stimulating the students to answer her question and from the answer she led them to understand the topic.

\section{Extract 3}

${ }^{5}$ L:Management strategies ...classroom management strategies, kalua misalnya tadi Cahyani keluar aja, dia masuk lagi apa yang akan saya lakukan? (If Cahyani went out without getting permission from me, then came in again, what would I do?) 


\section{S: Marah (became angry)}

${ }^{6}$ L: Marah? Apakahya? Kalau misalnya kejadian seperti itu, ya main keluar aja itu anak. Masuk dia lagi. (Became angry? Are you sure? If it happened, ya, a student did such the action), what would you do? 00:01:30)

\section{Using Example of Real Situation (UERS)}

In extract 3 , the example was taken from a real situation that could be seen by the students directly since the situation occurred in the classroom during the learning process. Such a technique of giving example encourages students to be involved mentally which can influence their learning development, for example, by asking a question or giving example.

In discussing classroom management and management strategies, the lecturer led the students to the concepts through questioning and answering techniques. During the classroom activity, one of the students asked permission to go out. While guiding the students to come to the concept, she illustrated the situation contextually (5 and 6). Context can be divided into formal, nonformal, and informal contexts (Tan, Armum, Chokkalingam, Meerah, Halim, Osman, \&Chellappan, 2017). Since communication occurs in the classroom, the most important context is the formal context. In this way, she showed the students the real situation and involved their emotions in deciding so that the students felt as if they were teachers. Cole \& Graham (2012) states teachers' or lecturer's language can cause ethical and joyful because it communicates students' emotions. It can be seen through the above extract, the lecturer did not explain the topic, but she inspiredthe students to think about the concept. However, the lack of contextual information made them misinterpret since their individual, social and cultural experience affected their cognitive context proposed by Sperber and Wilson (1986/1995), assumptions Insuitable for the interpretation of how cognitive context is created in the act of riddling. It is argued that this theory shows how and why thelnriddlee resorts to the cognitive context to give appropriate resolution $\backslash n$ to the riddle. In this regard, the cognitive context proposed by Relevance Theory is more powerful than the co-text or the context of nnsituation in giving appropriate interpretation to the riddle. The riddles under analysis are confined to one type of riddle, the metaphorical riddle, selected from Pepicello and Green's 1984 'The Language of Riddles'. The cognitive context here does not refer to thelnco-text or the context of situation but to the set of assumptions and beliefs in the mind of the riddlee about the world available to him in the process of riddle interpretation. The context determines the interpretation of an utterance while the lack of contextual information will lead to communication failure or misinterpretation. This relates to the fact that the cognitive context is affected differently by different individuals due to various factors ranging from one's cognitive abilitylnto one's social and cultural experiences. Hence, riddle interpretation, according to Relevance Theory, is an inferential process where cognitive context determines the interpretation of the riddle (Hussein \& Abdullah, 2016). Therefore, in contextualizing a text, examples are taken from the students' experiences to facilitate their understanding.

Power relations in the latest extract look a little bit balanced; the lecturer asked and the students answered. Examples given involved the situations that emerged during the learning process. The dialogic and conversational relation between the lecturer and the students observed from interactions, by which the lecturer asks and the students' answers. The power relation with which the lecturer still dominated the conversation undertaken in classroom interaction still occurred.

It is also observed that most students enjoyed the situation and did not feel under pressure when given a question. Each question requires an answer followed by another question. No marker describing a force to answer was indicated, so the students 
answered them spontaneously. Besides, the question involves the direction of the class. Consequently, the students felt relaxed and it is reflected in their faces and the way they answered the question. However, their engagement was restricted depending on the lecturer's question. Thus, this technique includes thefollowing up activities with group work. In collaborative settings, engagement becomes a more complex phenomenon than in individual learning settings (Jarvela, Malmberg, \& Isoh, 2016).

Regarding the students' engagement, Zimmerman \&Schunk (2011) as reviewed by Jarvela, Malmberg, \& Isoh (2016), suggest successful students do not only have a good strategy in learning but also have the willingness to learn. Moreover, they are involved behaviorally, intellectually, and emotionally in learning, which is called engagement. Engagement is a multidimensional construct of behavioral, emotional, and cognitive dimensions. First, behavioral engagement includes attendance and participation. Second, emotional engagement includes a sense of belonging and of valuing learning. Third, cognitive engagement is a willingness to engage in effortful tasks. Therefore, showing examples and asking students to find other examples are the lecturer's efforts to create students' learning climate and satisfaction in gaining the target of learning.

Because the question does not come from the students, the lecturer still dominates the classroom interaction. She decided what she wants to get from classroom interaction so that she prepared a few questions. Furthermore, directing the students to an answer 'apakah ini management strategy?' is the reflection of power. In a balanced power relation, the question must come out from the students, since the students are the individuals who want to learn and through their question, then when answering it they can learn what they need to know. In a research study done with clinical students, observations showed that the students thought that instruction meant getting experience to have the most of the opportunities (Graham \& Dornan, 2013).
Students fundamentally like to study through their own experience as depicted in their philosophy Alam takambang jadi guru" (learn by nature) (Nasroen, 1957, p. 35). When provided with a situation to experience to do new things and with the lecturer's guide, students will be engaged in classroom activity more actively. Moreover, the situation of the classroom environment such as cooperation, equity, and investigation. The Effects of Classroom Learning Environment and Laboratory Learning Environment on the Attitude towards Learning Science in the 21st Century Science (Karpudewan \& Meng, 2017). It can be created when using examples. Thus, the third findingis about the technique of Using the Example of Real Situation (UERS). To Maximalize students' Opportunity (MO), the lecturer can use an example taken from the Real Situation (RS) and use the Students' Question (SQ) so that lecturer-students' Power relation becomes Balanced. (BP).

The students' role in learning determines the power relation used by a lecturer in classroom interaction. Minangkabaunese students prefer learning with more examples than by using many words. The more words used by a lecturer in communicating with the students can impress that the lecturer supposes that the students know nothing so that every information should be detailed. It can be boring and harmful to them.

Classes, held by a group, work naturally to engage the students more than those held by individual work (Varelas, Pappas, \& Rife, 2006) . Lecturers' examples as models of learning while pre-phase learning activities can be helpful, but the models are followed by students' activities to find other examples, evaluate, and practice them during and after the classroom activities. It is supportive of empowering the students. Furthermore, it must promote changes by informing, enabling, motivating, and guiding participants (Bandura, 2001).

To make the power relation balanced in a certain discursive practice, a lecturer should realize that the students have individual 
differences, which causes them to perceive classroom action since they have different targets with separate techniques of achieving them (Strauman \& Wilson, 2010). As a result, some students may enjoy a task, while others hate it.

The lecturer's experience and sensitivity toward the context in which discursive practice emerges can direct her in choosing which example and how to use it so that the students can get the benefits. If more students in a classroom need to learn under the lecturer's guide the lecturer may create the situation in which she dominates power relations, but not vice versa. Moreover, the students' background knowledge also influences the lecturer in choosing examples. Finally, the power relation that is culturally appropriate for Minangkabaunese students is the mixture of the lecturer's domination and the students' domination. The lecturerstartscommunication by dominating power in the pre-phase stage but then followed by the students' domination in the following stage, so their power relation can be balanced.

\section{CONCLUSIONS AND RECOMMENDATIONS}

This research studied lecturers' techniques of using an example as intertextuality used in communicating learning tasks which can balance lecturerstudents' discourse. Three techniques were found (STDT, GETT, and UERS). STDT stands for Showing Technique of Doing Task.This technique influences students to be ready for doing the learning task. After giving a model, the lecturer asks the students to make examples, so the power relation in their discourse becomes balanced. GETT stands for Giving Example of the Task Topics. This technique was found ineffective to develop students' learning since it was dominated by the lecturer's activity. This technique is proposed to increase the students' learning development, which can be achieved if the lecturer limits the topics of examples, taken from students' previous knowledge, and uses Reciprocal Give-and-
Take and Here-and-Now examples. Through the ways, the lecturer's domination of power in the discourse can be reduced. Finally, UERS stands for Using Example of Real Situation. This technique maximalizes students' opportunity to learn by choosing examples from the real situation, followed by their questions. It makes them active in learning and the lecturer's power domination becomes reduced.

However, these research findings have some limitations as they were found from homogeneous participants, especially lecturers who taught at English Study Program, STKIP PGRI Sumatera Barat. Different participants with different contexts and backgrounds might need different techniques, so the findings may be more various if the study is broadened. Since this is a cross-sectional study, the techniques used by a lecturer might be dependent on the students' capability and their background knowledge. If the study is extended from one period to the other, the techniques may change from time to time or from certain situation to the other. Furthermore, since this research is purely qualitative, it does not touch quantitative data to find out the level of students' readiness, their learning development, and an increase in their effort in learning.

Based on the findings and the limitations of the research, researchers recommend lecturers and all teachers who teach adult learners to consider using examples when communicating the learning task to students. The techniques found in this research can be used as alternatives with some adaptations when they want to make students ready, well developed, or learn hard by considering their power relations. Moreover, it is recommended to other researchers do other researches on this topic by extending the methods and participants so that the newest and valuable techniques can emerge as the new science of teaching. 


\section{REFERENCES}

Amir, M. S. (2011). Adat minangkabau; pola dan tujuan hidup orang Minang. Jakarta: Citra Harta Prima.

Baker, P., \& Sibonile, E. (2011). Key terms in discourse analysis. New York: Continuum. New York: Continuum.

Bandura, A. (2001). Social cognitive theory of mass communication. Media Psychology, 3, 265-299. DOI: 10.1207/S1532785XMEP0303_03.

Bandura, A. (2002). Social cognitive theory in the cultural context.Applied Psychology: an International Review, 51(2), 269-290. DOI: 10.1111/14640597.00092 .

Bondareva, T.O., Khan, N.N., Pristupa, E.N., Dossanova, A.Z., Kremneva, T.L $\&$ and Rakymzhan Turysbek, R. (2017). The social and pedagogical characteristics of the future teacher's readiness for developing the intellectual and creative potential of a junior schoolchild in the heterogeneous ethnicenvironment. Pertanika J. Soc. Sci. \& Hum. 25 (S): 195 - 210.

Clare, S., Krogman, N., \& Caine, K. J. (2013). Geoforum the " balance discourse ": A case study of power and wetland management, 49, 40-49. Doi: 10.1016/j.geoforum.2013.05.007

Cole, D. R., \& Graham, L. J. (2012). The power in/of language. Chichester: Blackwell.

Fixsen, A., \& Ridge, D. (2012). Performance, emotional work, and transition: challenging experiences of complementary therapy student practitioners commencing clinical practice. Qualitative Health Research, 22(9) 1163-1175. DOI: $10.1177 / 1049732312449213$.

Gasparov, B. (2010). Speech, memory, and meaning intertextuality in everyday language. Berlin: De Gruyter.

Graham, J., \& Dornan, D. (2013). Power in clinical teachers' discourses of
curriculum-inaction-Critical discourse analysis. Adv in Health Sci Educ, 18975-985. DOI:10.1007/s10459-0129437-1

Harman, R. (2013). Literary intertextuality in genre-based pedagogies: Building lexical cohesion in fifth-grade L2 writing. Journal of Second Language Writing, Vol. 22 (2) 125-140. DOI: 10.1016/j.jslw.2013.03.006.

Hudson, R. A. (1985). Sociolinguistics. New York: Cambridge University Press.

Hussein, J. Q., \& Abdullah, I. H. (2016). The role of cognitive context in the interpretation of riddles: A relevance theory perspective. Pertanika Journal of Social Sciences and Humanities, 24 (February), 11-20.

Jarvela, S., Malmberg, J., \& Isoh, J. I. (2016). How do types of interaction and phases of self-regulated learning set a stage for collaborative engagement? Learning and Instruction XXX 1-13. DOI: 10.1016/j.learninstruc.2016.01.005

Karpudewan, M., \& Meng, C. K. (2017). The effects of the classroom learning environment and laboratory learning environment on the attitude towards learning science in the 21st-century science lessons. Malaysian Journal of Learning and Instruction, 272.

Keramati, A., Afshari-Mofrad, M., \& Kamrani, A. (2011). The role of readiness factors in E-learning outcomes: An empirical study. Computers and Education, 57 (3), 1919-1929. DOI:10.1016/j.compedu.2011.04.005

Khalidah K. A., Rohani, S.,\& Mashitah, S. (2014) Ethical values and commitment towards achieving excellence: a study on public boarding school students in Malaysia. Pertanika J. Soc. Sci. \& Hum. 22 (S): 33 - 50.

Krapp, K. (2005). Psychologists and their theories for students. New York: Thomson Gale. 
Learner-Centered Work Group of the American Psychological Association's Board of Education Affairs. Learnercentered psychological principles. A framework for school reform. November 1997.

Maeda, M. (2008). Power relations among actors in development cooperation: patterns, concepts, and approaches in a Japanese-assisted teacher training project in Canada. International Journal of Educational Development. Vol. 28 (5).

DOI:

10.1016/j.ijedudev.2007.05.005.

Manak, J. (2011). The social construction of intertextuality and literary understanding: the impact of interactive read-aloud during writing workshop. Reading Research Quarterly, 46 (4), 309-311. DOI: 10.1002/RRQ.001

Masuda, K., Arnett, C.,\&Labarca, A. (2015). Cognitive linguistics and sociocultural theory (applications for second and foreign language teaching). 3. A cognitive linguistic approach to teaching Chinese spatial particles: From contrastive constructional analysis to material design. Walter de Gruyter: DOI:10.1515/9781614514442.

Mayring, P. (2014). Quantitative content analysis. theoretical foundation: basic procedures and software solutions.

Metsärinne, M., Kallio, M., \& Virta, K. (2014). Pupils' readiness for selfregulated learning in the forethought phase of Exploratory Production. International Journal of Technology and Design Education, 25(1), 85-108. DOI: $10.1007 / \mathrm{s} 10798-014-9273-0$

Mizokawa, A. (2014). Theory of mind and sensitivity to teacher and peer criticism among Japanese children. Infant and Child Development. Vol. 4 (3). Doi: 10.1002/icd.1877

Myers, S. A. (2017a). A longitudinal analysis of students' motives for communicating with their instructors. Communication Education, 66(4), 467-473. DOI:

\section{$10.1080 / 03634523.2017 .1313437$}

Myers, S. A. (2017b). The instructor-student relationship as an alternative form of a superior-subordinate relationship. Communication Education, 66(1), 110112. DOI: 03634523.2016.1221513

Myers, S. A., \& Claus, C. J. (2012). The relationship between students' motives to communicate with their instructors and classroom environment. Communication Quarterly, 60(3), 386402.

DOI: $10.1080 / 01463373.2012 .688672$

Myrahil. (2013, March 2). Mengintip rahasia sukses orang minang.

Nasroen, M. (1957). Dasar Falsafah Minangkabau. Jakarta: Penerbit Pasaman.

Nassaji, H. (2007). Schema theory and knowledge-based processes in second language reading comprehension: a need for alternative perspectives. Language Learning, Vol. 57 (1) 79-133. DOI: 10.1111/2Fj.1467-9922.2007.00413.x.

Navis, A. A. (1984).Alam takambang jadi guru. Jakarta: Grafiti Pers.

Nevins, M. E. (2010). Nevins, M.Eleanor. 2010. "Intertextuality and misunderstanding. language and communication, Vol. 30 1-6. DOI: 10.1016/j.langcom.2009.10.001

Perumal, J. (2008). Student resistance and teacher authority: the demands and dynamics of collaborative learning. Journal of Curriculum Studies, Vol. 40 No 3 381-398. Doi: 10.1080/ 00220270701724570 ?

Pol, J. V., Volman, M., \& Beishuizen, J. (2011). A pattern of contingent teaching in teacher-student interaction. learning and instruction, 21 46-57. DOI:10.1016/j.learninstruc.

Ruiz, J. R. (Volume 10.No.2 Art.26.May 2009, May 26). Sociological discourse analysis: methods and logic." forum qualitative social research. Retrieved from http.www.qualitative. 
Shalihin, N. (2014). Demokrasi di nagarinya para tuan. Lubuk Lintah: Imam Bonjol Press.

Sternberg, R. J., \& Williams, W. M. (2010). Educational psychology (2nd ed.). Upper saddle river, New Jersey: Pearson Education.

Strauman, T. J., \& Wilson, W. A. (2010). Individual differences in approach and avoidance; behavioral activation/inhibition and regulatory focus as distinct levels of analysis. In R. $\mathrm{H}$. (ed), Handbook of personality and self-regulation (p. 447). Blackwell Publishing.

Syuhendri. (2012, February 14). Adat basandi syarak, syarak basandi kitabullah.

Tan, S. K., Armum, P., Chokkalingam, A. I., Meerah, T. S. M., Halim, L., Osman, K. and Chellappan, K. Communication: uses and influence of employment among youths: the role of formal education.Pertanika J. Soc. Sci. \& Hum. 25 (S): 21 - 34 (2017).

Van-Dijk, T. A. (2008). Discourse Power. New York: Palgrave Macmillan.

Varelas, M., Pappas, C. C., \& Rife, R. (2006). Exploring the role of intertextuality in concept construction: urban second graders make sense of evaporation, boiling, and condensation. Journal of Research in Science Teaching, Vol. 43, No. $7 . \quad 637-666 . \quad$ DOI: 10.1002/tea.20100.

Vollmeyer, R., \& Rheinberg. , F. (2006). Motivational effects on self-regulated learning with different tasks. Educ Psychol Rev, 239-253. DOI:10.1007/s10648-006-9017-0

Warren, M. (2013). “Just spoke to ...': The types and directionality of intertextuality in professional discourse. Martin Warren. The types and directionality of intertextuality in English for Specific Purposes, Vol 32 (1) 1-24. DOI: 10.1016/j.esp.2012.07.001.
Weibell, C. J. Principles of learning: A conceptual framework for domainspecific theories of learning.

Yasnitsky, A. (2007). Vygotsky circle as a personal network of scholars:restoring connections between people and ideas. Integr Psych Behav (2011) 45:422-457. DOI: $10.1007 / \mathrm{s} 12124-011-9168-5$.

Yelfiza. (2016, February 5). Ideology and power of the lecturers' classroom discourse in communicating learning tasks at the university level. unpublished Dissertation.UNP (State University of Padang): Padang, Sumatera Barat, Indonesia.

Yelfiza., Yulmiati., \& Sukandi, S.S. (2016). English lecturers' thematic intertextuality in communicating learning tasks to Minangkabaunese students.5 ICLLCE 2016 (pp. 64-77). Singapore: icsai.org.

Zhang, Z., \& Verhaeghen, P. (2009). Glimpses of a one-speed mind: Focusswitching and search for verbal and visual, and easy and difficult items in working memory. Acta Psychologica, Vol. $13 \quad$ (1 235-244. DOI: 10.1016/j.actpsy.2009.05.009. 